The infectivity of the ribonucleic acid preparation is about 0.1 per cent of that of the same amount of ribonucleic acid contained in native tobacco mosaic virus. Whether this relatively low valuo is due to a large inactive fraction of the ribonucleic acid preparation, or to low efficiency of the mechanism of infection, has still to be determined.

Studies on the combination of the ribonucleic acid with proteins are being carried out and may elucidate the connexion between our findings and the reactivation experiments of Fraenkel-Conrat and Williams ${ }^{4}$, of Lippincott and Commoner ${ }^{5}$, and of Hart ${ }^{6}$.

We are much indebted to Prof. H. Friedrich-Freksa for helpful discussions, to Mr. R. Engler and Dr. H. Schuster for their co-operation, and to Miss A. Kleih for assistance.

A detailed account of this work will be published in the Zeitschrift für Naturforschung.

A. GIERER

G. Schramin

Max-Planck-Institut für Virusforschung, Tübingen.

Feb. 10 .

${ }^{1}$ Hershey, A. D., and Chase, M., J. Gen. Physiol., 36, 39 (1952).

${ }^{2}$ Schramm, $G_{i}$ and Miller, $H_{1}$ Hoppe Seylers $Z$. physiol. Chem. 266, 43 (1940); 274, 267 (i942). Miller, G. L and Stanley W. M., J Biol. Chem., 141, 905 (1941); 146, 331 (1942). Harris, J. I., and Knight, C. A., J. Biol. Chem., 214, 215 (1955).

s Schramm, G., Schumacher, G., and Zillig, W., Nature, 175, 549 (1955).

- Fraenkel-Conrat, H., and Williams, R. C., Proc. O.S. Nat. Acad Sci., 41, 690 (1955).

'Lippincott, J. A., and Commoner, B., Biochim. Biophys. Acta, 19, Hart, R. G., Nature, 177, 130 (1956).

\section{A Possible Mode of Action of 2 : 4-Diamino-5-phenyl-thiazole Hydrochloride (Daptazole or Amiphenazole)}

SOME pharmacological properties and clinical uses of $2: 4$-diamino-5-phenyl-thiazole hydrochloride (daptazole or amiphenazole) have been previously considered elsewhere ${ }^{1}$. It often appears to exert a mild respiratory stimulant effect in both unnarcotized and narcotized patients and animals. It has been used clinically as a buffer to depressed respiration in such conditions as pneumonia, asphyxia neonatorum and in the relief of respiratory depression following annsthesia. It has further been employed in the treatment of barbiturate intoxication (usually in combination with $\beta \beta$-methyl ethyl glutarimide (NP13, megimide or bemegride)) and opiate overdosage, and has been administered in combination with large doses of morphine in the relief of severe and prolonged pain. When used in this latter manner, it has appeared to minimize the onset of tolerance or addiction to morphine. It is effective both orally and parenterally, and has a high therapeutic index (greater than 10). Therapeutic doses $(5-50 \mathrm{mgm}$.) are almost completely devoid of side effects, and large doses (more than $200 \mathrm{mgm}$.) have been safely tolerated by unnarcotized volunteers. In small doses (20-40 mgm.) it ofton appears to improve the mental outlook of depressed patients.

The fact that daptazole has such widespread activity and that such large doses have been safely tolerated has suggested that this substance may fit into some fundamental physiological process.

As the structures of daptazole and the thiazole noiety of thiamine (4-methyl-5-hydroxy-ethyl-thia-
Table 1

All rats on a thiamine-free diet. 10 animals in each group

\begin{tabular}{|c|c|c|c|c|c|c|}
\hline \multirow{2}{*}{ Group } & \multicolumn{3}{|c|}{$\begin{array}{l}\text { Drugg administered } \\
\text { (mgm./kgm. } \\
\text { intraperitoneally) }\end{array}$} & \multirow{2}{*}{$\begin{array}{l}\text { Period } \\
\text { of } \\
\text { adapta- } \\
\text { tion } \\
\text { (days) }\end{array}$} & \multirow{2}{*}{$\begin{array}{l}\text { Onset of } \\
\text { thiamine- } \\
\text { deficiency } \\
\text { symptoms }\end{array}$} & \multirow{2}{*}{$\begin{array}{l}\text { Reversa } \\
\text { by vita- } \\
\text { min } \mathrm{B}_{1}\end{array}$} \\
\hline & $\begin{array}{l}\text { Dapt- } \\
\text { azole }\end{array}$ & $\underset{B_{1}^{*}}{\mathrm{Pyr}^{*}}$ & $\begin{array}{l}\text { Fre- } \\
\text { quency }\end{array}$ & & & \\
\hline Control & 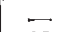 & $\ldots$ & - & - & $2-3$ weeks & + \\
\hline 1 & 10 & $2 \cdot 5$ & $\begin{array}{l}\text { three } \\
\text { times } \\
\text { daily }\end{array}$ & $7-10$ & $\begin{array}{l}\text { None for } \\
9 \text { weeks }\end{array}$ & - \\
\hline 2 & 50 & $12 \cdot 5$ & daily & - & 10 days & + \\
\hline 3 & 50 & - & daily & - & $4-5$ weeks & + \\
\hline 4 & & $12 \cdot 5$ & daily & - & 3-4 weeks & + \\
\hline
\end{tabular}

* Pyr. $B_{1}=2$-methyl-4-amino-5-brom-methyl-pyrimidine dihydrobromide.

zole) show some similarity and, further, as thiamine appears to be the only substance occurring naturally in the body which contains the thiazole nucleus, experiments were performed in which rats $(40-50 \mathrm{gm}$. on a thiamine-free diet were given daily intraperitoneal injections of daptazole and the pyrimidine moiety of thiamine (2-methyl-4-amino-5-brommethyl-pyrimidine dihydrobromide) to see if the combination of these two drugs would produce a substance capable of entering into thiamine metabolism ${ }^{2}$

Preliminary results (Table I) indicate that rats, maintained on low doses of these drugs $(10 \mathrm{mgm} . / \mathrm{kgm}$. daptazole hydrochloride; $2.5 \mathrm{mgm}$./kgm. 2-methyl4-amino-5-brom-methyl-pyrimidine dihydrobromide given intraperitoneally three times daily), after a period of adaptation (seven to ten days), showed no signs or symptoms of thiamine avitaminosis nine weeks after the commencement of the treatment, whereas their controls were clearly deficient in thiamine in three weeks and had all died in five weeks.

The results also indicate that the symptoms of thiamine deficiency developed in rats maintained on a thiamine-free diet could be reversed by similar administration of these doses of daptazole and the pyrimidine moiety of thiamine. However, the daily administration of larger doses of daptazole $(50 \mathrm{mgm}$. $\mathrm{kgm}$.) and the pyrimidine moiety of thiamine $(12.5 \mathrm{mgm} . / \mathrm{kgm}$.) to such rats appeared to bring about a more rapid induction of thiamine avitaminosis which could be reversed by the administration of thiamine. This more rapid onset of thiamine avitaminosis was not produced when either drug was given alone in these larger doses, and indeed the condition of these animals seemed better than that of their control groups. These observations suggest. that daptazole may enter into the pathway of processes involving thiamine. This may be one of its modes of action, and could serve to afford some rationale for its wide sphere of clinical and pharmacological actions in apparently unrelated and diverse processes which may be dependent on thiamine.

This hypothesis is now being investigated and a full account will be published elsewhere.

Department of Physiology,

A. ShULMan

University of Melbourne. Nov. 28

1 Shaw, F. H., and Bentley, G. Nature, 169, 712 (1952); Aust. J. Exp. Biol.' 33, 143 (1955) Shaw, F. H., and Shulman, A., Nature, Shaw, F. H., Cass, N. M., and Whyte, H. M., Brit. Med. J., i, $1238(1955)$.

${ }^{2}$ Abderhajden, R., Pfü̈g. Arch, ges. Physiol, 273, 762 (1939-40). 